\title{
ANALISIS PENGARUH PARAMETER DEWATERING TERHADAP PENURUNAN MUKA AIR TANAH DAN TEGANGAN PADA TANAH
}

\author{
Denissa Permatasari ${ }^{1}$, Gregorius Sandjaja ${ }^{2}$ \\ ${ }^{1}$ Program Studi Sarjana Teknik Sipil, Universitas Tarumanagara, Jl. Letjen S. Parman No.1 Jakarta \\ Email: permata.den@gmail.com \\ ${ }^{2}$ Program Studi Sarjana Teknik Sipil, Universitas Tarumanagara, Jl. Letjen S. Parman No.1 Jakarta \\ Email:gregoriuss@ft.untar.ac.id
}

\begin{abstract}
ABSTRAK
Dewatering sangat dipengaruhi oleh parameter dewatering, yaitu dalam penelitian ini adalah koefisien permeabilitas dan storage coefficient. Penelitian ini menggunakan data dari studi kasus suatu proyek di Jl. Sudirman, Jakarta Pusat untuk menganalisis parameter-parameter tersebut. Untuk analisis akurasi rumus empiris yang digunakan sebagai sumber alternatif koefisien permeabilitas selain dari tes lapangan dan laboratorium, dilakukan pemodelan dengan program GeoStudio SEEP/W. Dari hasil pemodelan SEEP/W ditemukan bahwa muka air tanah pada model dengan nilai koefisien permeabilitas dari rumus Gustafson, yang menggunakan ukuran butir tanah, paling mendekati muka air tanah dari data lapangan. Untuk analisis storage coefficient ditemukan bahwa tiap $1 \%$ storage coefficient menghasilkan volume air sebesar $8.7104 \mathrm{~m}^{3}$. Penurunan muka air tanah juga menimbulkan perubahan tegangan tanah pada struktur penahan tanah yang digunakan di proyek tersebut, yaitu $D$ wall. Penelitian ini juga menganalisis efek perubahan tegangan tanah tersebut sebagai perbedaan lendutan yang terjadi pada $D$-wall. Ditemukan bahwa penurunan beda muka air tanah di kedua sisi $D$ wall sebesar $3 \mathrm{~m}$ mengurangi lendutan di tengah bentang terpanjang $D$-wall sebesar $2.2 \mathrm{~mm}$.
\end{abstract}

Kata kunci: dewatering, hukum Darcy, koefisien permeabilitas, storage coefficient, D-wall

\section{PENDAHULUAN}

Adanya air tanah sangat mempengaruhi proses konstruksi fondasi dan basement. Bila tanah digali hingga di bawah muka air tanah (MAT), air tersebut akan terus mengalir keluar hingga habis. Agar tidak mengganggu proses konstruksi, MAT dapat diturunkan dengan cara dewatering. Proses dewatering yang dikenal ada beberapa macam, yang digunakan pada proyek X di Jl. Sudirman yang menjadi studi kasus adalah predrainage dan cut-off wall (Powers: 1981). Proses dewatering sangat dipengaruhi oleh berbagai parameter tanah yang berkaitan dengan dewatering. Parameter dewatering yang akan dianalisis adalah koefisien permeabilitas/permeability $(K)$, dan storage coefficient $\left(C_{s}\right)$. Penurunan MAT juga menyebabkan perubahan tegangan lateral yang bekerja pada struktur $D$-wall yang merupakan dinding penahan tanah dan cut-off wall yang digunakan pada proyek X.

Air yang mengalir melalui rongga di antara butiran tanah mengalami gesekan sehingga memenuhi hukum Darcy (Powers: 1981). Kecepatan aliran air melalui butiran tanah (permeabilitas) dan banyaknya air yang dapat dilepaskan oleh butiran tanah (storage coefficient) sangat tergantung pada tekanan kohesi antara air dengan butiran tanah (Bilskie: 2001). Sehingga, selain dari pump test di lapangan, nilai koefisien permeabilitas dapat diperkirakan secara empiris dengan menggunakan soil grading yang didapat dari tes laboratorium.

Seluruh rumus yang digunakan dalam penelitian ini berlaku untuk air tanah/aquifer tipe water table/unconfined, dimana nilai specific yield sama dengan storage coefficient.

\section{STUDI KASUS PROYEK X DI JL. SUDIRMAN}

Proyek X yang menjadi studi kasus penelitian ini adalah proyek gedung perkantoran di Jl. Sudirman dengan basement 5 lantai (kedalaman -17.6 m). Sumber data untuk proyek ini adalah wawancara dengan subkontraktor dewatering, hasil tes lapangan dan laboratorium Soil Report, data monitoring harian dewatering Piezometer Report dengan informasi MAT dan debit pompa dewatering, dan laporan Analisis Pergerakan D-wall oleh manajemen konstruksi proyek sebagai sumber data posisi lantai basement dan kekakuan $D$-wall.

Data dari semua Piezometer Report yang telah diolah dan disusun menjadi grafik untuk memudahkan pemilihan data dapat dilihat sebagai berikut: 


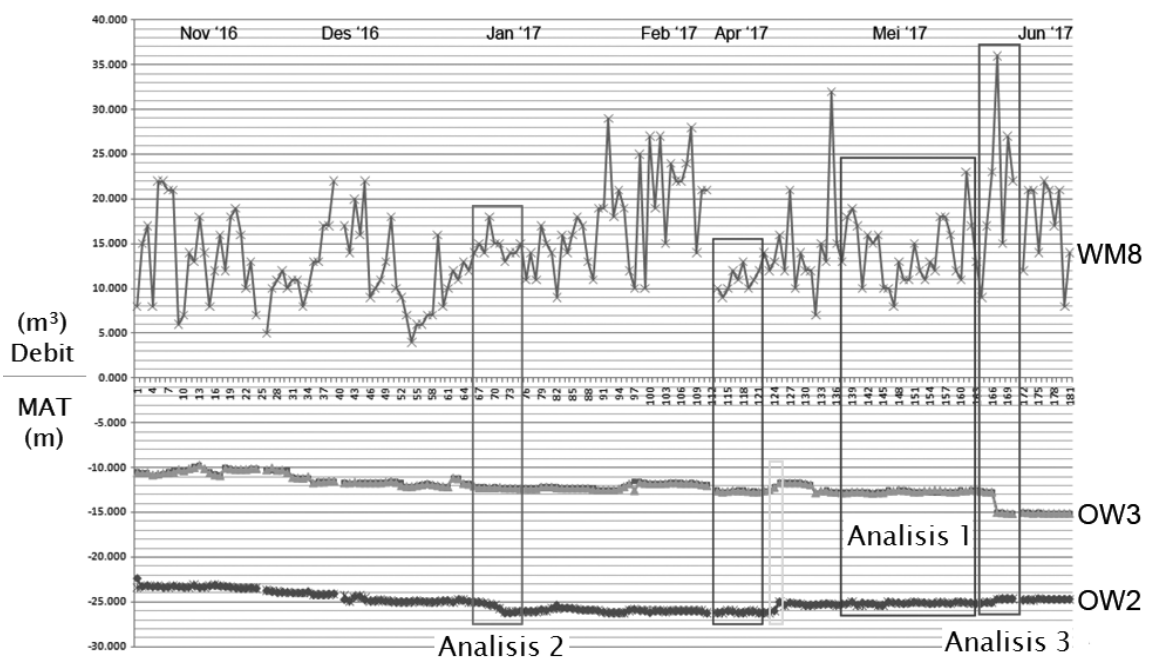

Gambar 1. Grafik data dari semua Piezometer Report dan periode yang dianalisis

\section{Hasil wawancara}

- D-wall yang digunakan impermeabel karena berfungsi sebagai dinding penahan galian basement yang menggunakan sistem top-down

- Pengawasan pompa dilakukan 24 jam dan rutin dibersihkan secara berkala

- Sebagian air yang dipompa dikembalikan ke recharge well (RW) untuk menjaga kondisi MAT stabil

- Tidak ada/minim komunikasi dengan proyek yang mengerjakan konstruksi tower di kavling yang berdekatan, sehingga efek dewatering pada kondisi tanah di proyek tetangga tidak diketahui

\section{ANALISIS PARAMETER DEWATERING}

Parameter dewatering yang akan dianalisis yaitu koefisien permeabilitas/permeability $(K)$, dan storage coefficient $\left(C_{s}\right)$. Digunakan data lapangan yang sudah ada sebagai perbandingan terhadap hasil yang didapat secara empiris.

\section{Analisis 1: Koefisien permeabilitas (K)}

Digunakan program GeoStudio SEEP/W untuk memodelkan MAT yang terjadi pada nilai koefisien permeabilitas tertentu. Kondisi lapangan dan data Piezometer Report dari April 29 - Mei 9, 2017 digunakan untuk menyusun model SEEP/W dan data tanah dari DB2 dalam Soil Report pada kedalaman $26 \mathrm{~m}-27.5 \mathrm{~m}$ sebagai input parameter pada soil region. Dalam manual untuk program tersebut diharuskan membuat model yang sesederhana mungkin agar hasil simulasi lebih konsisten (GEO-SLOPE International Ltd: 2012), sehingga digunakan satu lapisan tanah yang dapat mewakili seluruh model hingga lapisan tanah keras/lantai dasar aquifer pada kedalaman -36 m. Menggunakan lebih dari satu lapisan untuk analisis dewatering tidak berpengaruh secara signifikan (Demirbas: 2012). Data-data tersebut dapat dilihat pada tabel-tabel berikut ini:

Tabel 1. Data boundary condition MAT dan debit dari Piezometer Report untuk model SEEP/W

\begin{tabular}{|c|c|c|c|c|}
\hline Tanggal & OW1 & OW2 & OW3 & DW8 \\
\hline$(2017)$ & & (m) & & (m3) \\
\hline Apr 29 & -23.600 & -25.000 & -12.700 & 15 \\
\hline 30 & -23.600 & -25.100 & -12.700 & 12 \\
\hline Mei 1 & -23.600 & -25.100 & -12.700 & 11 \\
\hline 2 & -23.600 & -25.200 & -12.800 & 13 \\
\hline 3 & -23.600 & -25.200 & -12.800 & 12 \\
\hline 4 & -23.700 & -25.000 & -12.800 & 18 \\
\hline 5 & -23.700 & -25.100 & -12.800 & 18 \\
\hline 6 & -23.700 & -25.200 & -12.800 & 16 \\
\hline 7 & -23.700 & -25.100 & -12.700 & 12 \\
\hline 8 & -24.700 & -25.000 & -12.500 & 11 \\
\hline 9 & -24.900 & -25.100 & -12.700 & 23 \\
\hline Rata2: & -23.700 & -25.100 & -12.700 & 15 \\
\hline
\end{tabular}


Tabel 2. Data tanah pada kedalaman $26 \mathrm{~m}-27.5 \mathrm{~m}$ dari DB2 Soil Report

\begin{tabular}{ll}
\hline $\mathrm{D}_{10}$ & $0.001 \mathrm{~mm}$ \\
\hline $\mathrm{D}_{60}$ & $0.008 \mathrm{~mm}$ \\
\hline Saturated water content & $0.7234 \mathrm{~m}^{3} / \mathrm{m}^{3}$ \\
\hline Residual water content & $0.4 \mathrm{~m}^{3} / \mathrm{m}^{3}$ \\
\hline
\end{tabular}

Denah dewatering sebagai posisi boundary condition titik-titik MAT yang diketahui dan titik pompa, dan juga penjelasan tebal elemen $1 \mathrm{~m}$ dan jarak titik pompa ke potongan model sebesar $16.7426 \mathrm{~m}$ sehingga debit pompa dibagi dengan jarak tersebut, dapat dilihat sebagai berikut:
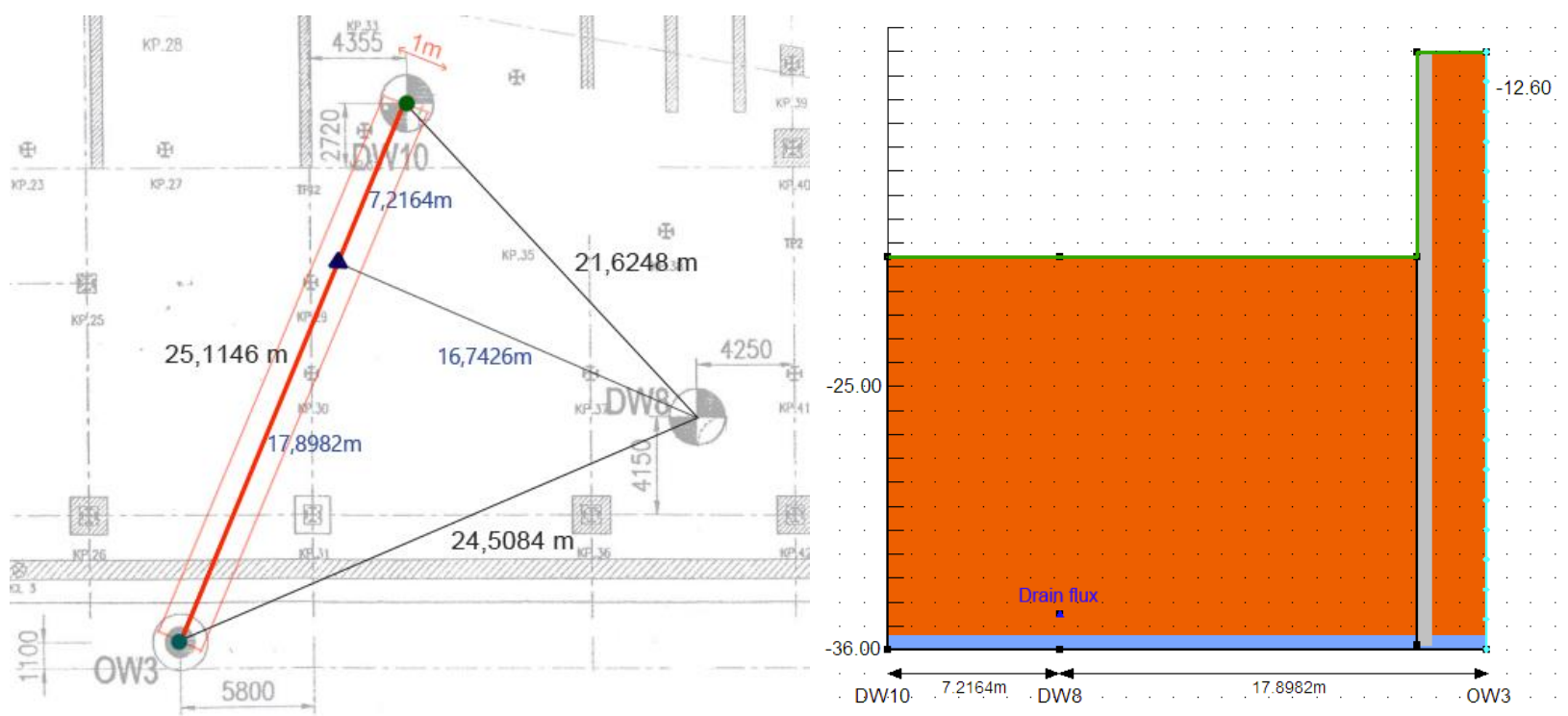

Gambar 1. Denah dewatering dan potongan 1m (kiri) \& 2. Tampak model SEEP/W (kanan)

Model SEEP/W membutuhkan kondisi awal steady state sebelum dapat dilakukan analisis transient state selama beberapa hari untuk melihat pergerakan MAT pada nilai koefisien permeabilitas tertentu. Dalam Analisis 1 akan diperbandingkan hasil MAT dalam model SEEP/W dari 3 nilai koefisien permeabilitas, dari pump test dalam Soil Report, rumus Gustafson, dan rumus Darcy yang dimodifikasi oleh Vesilind untuk unconfined aquifer.

Kondisi awal steady state model dan hasil MAT pada model SEEP/W dengan nilai K dari Soil Report: $6.82 \times 10^{-4}$ $\mathrm{m} /$ detik dapat dilihat sebagai berikut:
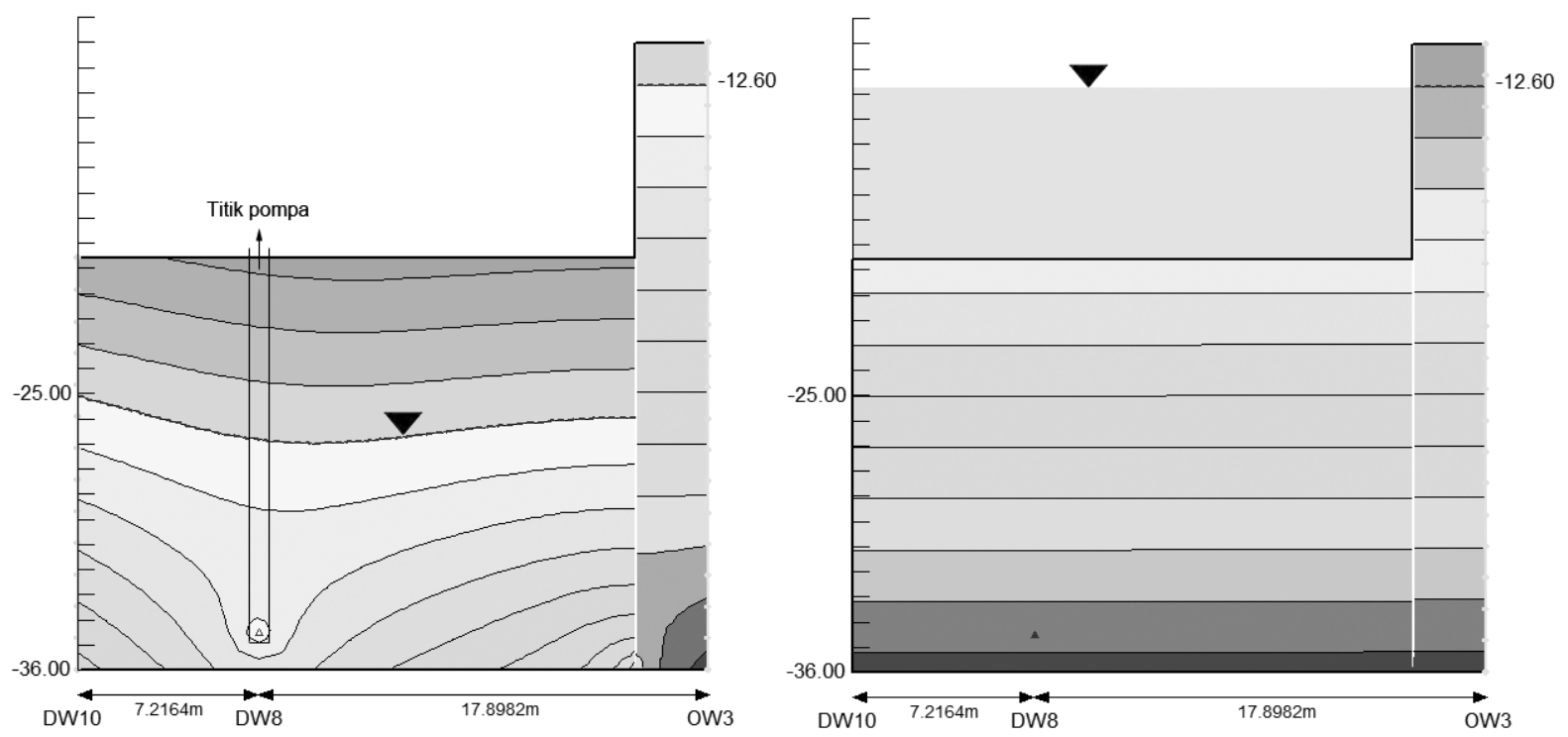

Gambar 3. Model kondisi awal steady state (kiri) \& 4. Kondisi MAT dengan K dari Soil Report (kanan) 
Dibandingkan dengan kondisi lapangan sebenarnya, model dengan K dari Soil Report $6.82 \times 10^{-4} \mathrm{~m} / \mathrm{detik}$ banjir secara drastis. Dengan rumus Gustafson, didapat K secara empiris menggunakan soil grading, sebagai berikut:

Coefficient of uniformity $\left(\mathrm{C}_{\mathrm{u}}\right)$ untuk ukuran butir tanah:

$$
C_{u}=\frac{D_{60}}{D_{10}}=\frac{0.008}{0.001}=8
$$

Dengan $\mathrm{D}_{60}=$ ukuran butir tanah pada fraksi lolos $60 \%$, dan $\mathrm{D}_{10}=$ ukuran butir tanah pada fraksi lolos $10 \%$.

$\mathrm{g}\left(\mathrm{C}_{\mathrm{u}}\right), \mathrm{E}$, dan $\mathrm{E}\left(\mathrm{C}_{\mathrm{u}}\right)$ sebagai variabel tanpa satuan dengan fungsi sebagai berikut:

$$
\begin{gathered}
g\left(C_{u}\right)=\frac{1.3}{\log _{10} C_{u}} \cdot \frac{C_{u}^{2}-1}{C_{u}^{1.8}}=\frac{1.3}{\log _{10} 8} \cdot \frac{8^{2}-1}{8^{1.8}}=2.181877 \\
E=0,8 \cdot \frac{1}{2 \cdot \ln \left(C_{u}\right)}-\frac{1}{C_{u}^{2}-1}=0,8 \cdot \frac{1}{2 \cdot \ln (8)}-\frac{1}{8^{2}-1}=0.176486 \\
E\left(C_{u}\right)=10,2 \cdot 10^{6} \cdot \frac{E^{3}}{1+E} \cdot \frac{1}{g\left(C_{u}\right)^{2}}=10,2 \cdot 10^{6} \cdot \frac{0.176486^{3}}{1+0.176486} \cdot \frac{1}{2.181877^{2}}=1011.1924
\end{gathered}
$$

K dari rumus Gustafson (Svensson: 2014):

$$
K=E\left(C_{u}\right) \cdot\left(\frac{D_{10}}{1000}\right)^{2}=1011.1924 \cdot\left(\frac{0.001}{1000}\right)^{2}=1.00112 \times 10-8 \mathrm{~mm} / \mathrm{detik}
$$

Dalam $\mathrm{m} /$ hari $=\mathrm{K}=1.00112 \times 10^{-5} \mathrm{~m} /$ detik.

Dengan rumus Darcy/Vesilind, digunakan data rata-rata pada Tabel 1 untuk $\mathrm{Q}=$ debit air dan $\mathrm{h}=$ jarak MAT ke lantai dasar aquifer di suatu titik, dan denah sebagai berikut untuk mendapatkan $\mathrm{r}=$ jarak dari suatu titik ke pompa:

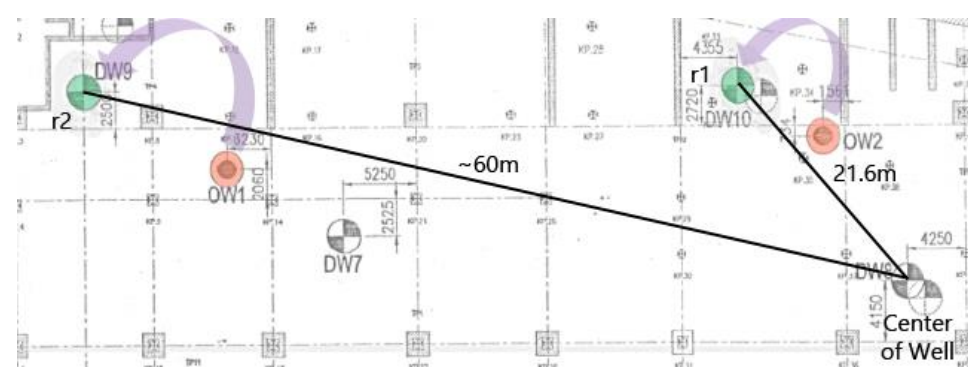

$$
\begin{aligned}
& \mathrm{Q}=15 \mathrm{~m}^{3} / \mathrm{s} \\
& \mathrm{r}_{1}=21.6 \mathrm{~m} \\
& \mathrm{~h}_{1}=36 \mathrm{~m}-25.1 \mathrm{~m}=10.9 \mathrm{~m} \\
& \mathrm{r}_{2}=60 \mathrm{~m} \\
& \mathrm{~h}_{2}=36 \mathrm{~m}-23.7 \mathrm{~m}=12.3 \mathrm{~m}
\end{aligned}
$$

Gambar 5. Denah dan data untuk rumus Darcy/Vesilind

K dari rumus Darcy/Vesilind (Vesilind: 1994) dapat dilihat sebagai berikut:

$$
\mathrm{K}=\frac{\mathrm{Q} \ln \frac{\mathrm{r}_{1}}{\mathrm{r}_{2}}}{\pi\left(\mathrm{h}_{1}^{2}-\mathrm{h}_{2}^{2}\right)}=\frac{15 \ln \frac{21.6}{60}}{\pi\left(10.9^{2}-12.3^{2}\right)}=0.150185 \mathrm{~m} / \mathrm{hari}
$$

Dijadikan m/detik, $\mathrm{K}=1.73826 \times 10^{-6} \mathrm{~m} /$ detik

Hasil MAT pada model SEEP/W dengan nilai K dari rumus Gustafson $\left(1.00112\right.$ x $\left.10^{-5} \mathrm{~m} / \mathrm{detik}\right)$ dan dari rumus Darcy/Vesilind dapat dilihat sebagai berikut:
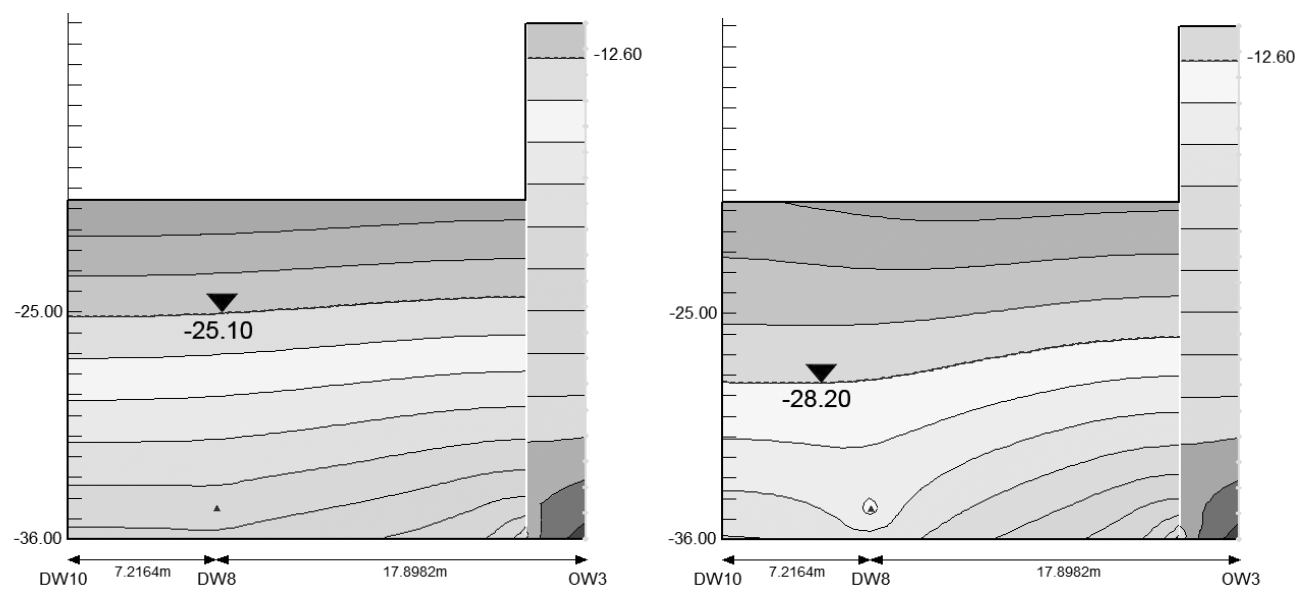

Gambar 6. Hasil MAT pada model SEEP/W dari rumus Gustafson (kiri) \& 7. Dari rumus Darcy/Vesilind (kanan) 
Rangkuman hasil MAT dalam model dari 3 nilai K yang berbeda dapat dilihat sebagai berikut:

Tabel 3. Rangkuman hasil pemodelan SEEP/W dengan nilai K tertentu

\begin{tabular}{cccc}
\hline Kondisi & $\begin{array}{c}\text { K } \\
(\mathrm{m} / \text { detik })\end{array}$ & $\begin{array}{c}\text { MAT } \\
(\mathrm{m})\end{array}$ & $\begin{array}{c}\text { Beda } \\
(\mathrm{m})\end{array}$ \\
\hline Lapangan & & -25.1 & - \\
\hline Soil report & $6.82 \times 10^{-4}$ & banjir & - \\
\hline Gustafson & $1.00112 \times 10^{-5}$ & -25.1 & 0 \\
\hline Vesilind & $1.73826 \times 10^{-6}$ & -28.2 & -3.1 \\
\hline
\end{tabular}

Dari hasil simulasi model SEEP/W, nilai $\mathrm{K}$ yang menghasilkan MAT yang paling mendekati kondisi MAT sebenarnya di lapangan adalah nilai K dari rumus empiris Gustafson. Sementara itu nilai K dari Soil Report dan dari rumus Darcy/Vesilind jauh dari kondisi lapangan.

Dalam tabel berikut dilakukan perhitungan nilai $\mathrm{K}$ dari referensi yang menggunakan grain size analysis dari DB2 kedalaman $26.5 \mathrm{~m}-27 \mathrm{~m}$ (Quinion: 1987):

Tabel 4. Nilai K fraksional

\begin{tabular}{lcccc}
\hline \multicolumn{1}{c}{ Soil type } & $\begin{array}{c}\text { Grading } \\
(\mathbf{m m})\end{array}$ & $\begin{array}{c}\mathbf{K} \\
(\mathbf{m} / \mathbf{s})\end{array}$ & Fraction & $\begin{array}{c}\text { K } \\
\text { Fractional }\end{array}$ \\
\hline Fine sand & $0.2-0.05$ & $>10^{-4}$ & $10 \%$ & $1 \times 10^{-5}$ \\
\hline Coarse silt & $0.05-0.02$ & $>10^{-5}$ & $20 \%$ & $2 \times 10^{-6}$ \\
\hline Medium silt & $0.02-0.005$ & $>10^{-6}$ & $30 \%$ & $3 \times 10^{-7}$ \\
\hline Fine silt & $0.005-0.002$ & $>10^{-7}$ & $20 \%$ & $2 \times 10^{-8}$ \\
\hline Clays & $<0.002$ & $<10^{-7}$ & $20 \%$ & $2 \times 10^{-9}$ \\
\hline & & Total & $\mathbf{1 0 0 \%}$ & $\mathbf{1 . 2 3 2 2 ~} \mathbf{1 0}^{-5}$ \\
\cline { 2 - 4 }
\end{tabular}

Dapat disimpulkan bahwa nilai K dari Soil Report sebesar $6.82 \times 10^{-4}$ jauh lebih besar dari nilai kisaran K untuk jenis tanah silty clay yaitu $>10^{-5}$.

\section{Analisis 2: Storage coefficient $\left(\mathrm{C}_{\mathrm{s}}\right)$}

Untuk menganalisis storage coefficient digunakan rumus Darcy/Vesilind untuk menggambar kurva MAT pada tanah setelah penurunan yang signifikan untuk menghitung volume tanah yang mengeluarkan air dengan cara integral benda putar.

Tabel 5. Kondisi awal dan kondisi akhir debit dan MAT (Januari 2017)

\begin{tabular}{ccc}
\hline \multicolumn{3}{c}{ Kondisi Awal } \\
\hline Tanggal & $\begin{array}{c}\text { OW2 } \\
(\mathrm{m})\end{array}$ & $\begin{array}{c}\text { DW8 } \\
\left(\mathrm{m}^{3}\right)\end{array}$ \\
\hline 10 & -25 & 12 \\
\hline 11 & -24.8 & 11 \\
\hline 12 & -24.8 & 13 \\
\hline 13 & -25 & 12 \\
\hline 14 & -25 & 14
\end{tabular}

\begin{tabular}{ccc}
\hline \multicolumn{3}{c}{ Kondisi Akhir } \\
\hline Tanggal & $\begin{array}{c}\text { OW2 } \\
(\mathrm{m})\end{array}$ & $\begin{array}{c}\text { DW8 } \\
\left(\mathrm{m}^{3}\right)\end{array}$ \\
\hline 15 & -25 & 15 \\
\hline 16 & -25.1 & 14 \\
\hline 17 & -25.25 & 18 \\
\hline 18 & -25.4 & 15 \\
\hline 19 & -25.75 & 15
\end{tabular}

Untuk mendapatkan kurva MAT dengan kordinat x dan y, rumus Darcy/Vesilind disusun menjadi berikut:

$$
y=\sqrt{h_{1}^{2}-\frac{Q \ln \frac{r_{1}}{x}}{\pi K}}
$$

dimana $\mathrm{y}=\mathrm{h}_{2}$ (MAT pada posisi $\left.\mathrm{x}=\mathrm{r}_{2}\right)$, dan $\mathrm{Q}=$ debit air.

Denah yang digunakan sebagai luas daerah dan titik-titik untuk rumus Darcy/Vesilind dapat dilihat sebagai berikut: 


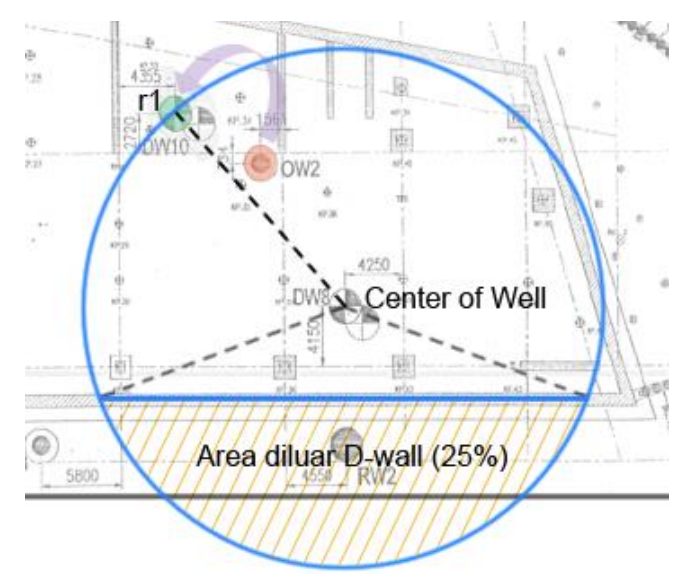

Gambar 8. Denah luas daerah didalam $D$-wall dengan OW2 sebagai $\mathrm{r}_{1}$

Dari denah tersebut diketahui bahwa $r_{1}=21.6 \mathrm{~m}$. Untuk menghitung kurva dengan rumus (7) digunakan rata-rata dari data kondisi awal dan kondisi akhir, dapat dilihat pada tabel berikut ini:

Tabel 6. Rata-rata data kondisi awal dan akhir untuk menggambar kurva MAT

\begin{tabular}{ccccc}
\hline Kondisi & OW2 & h1 & Q & K \\
\hline Awal & $-25.00 \mathrm{~m}$ & $11 \mathrm{~m}$ & $12 \mathrm{~m}^{3} /$ hari & $0.864968 \mathrm{~m} /$ hari \\
\hline Akhir & $-25.75 \mathrm{~m}$ & $10.25 \mathrm{~m}$ & $77 \mathrm{~m}^{3} / 5$ hari & $4.3248 \mathrm{~m} / 5$ hari \\
\hline
\end{tabular}

Dari data tersebut didapatkan fungsi kurva untuk kondisi awal:

$$
y_{\text {awal }}=\sqrt{121-4.416024 \ln \frac{21.6}{x}}
$$

Dan rumus untuk kondisi akhir:

$$
y_{\text {akhir }}=\sqrt{105.0625-5.667231 \ln \frac{21.6}{x}}
$$

Sehingga dapat digambarkan kurva MAT untuk mencari luas integral:

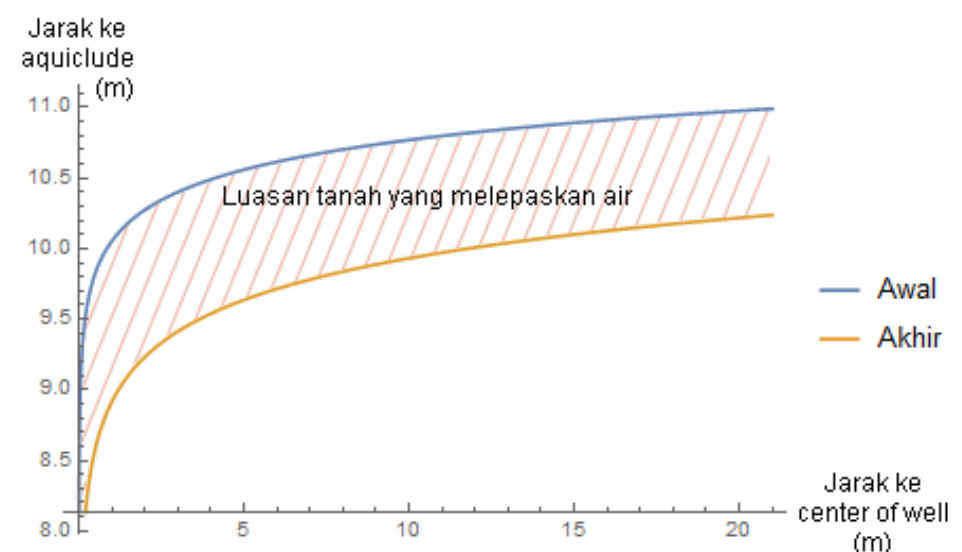

Gambar 9. Luas integral MAT yang melepaskan air dari rumus Darcy/Vesilind

Volume tanah yang melepaskan air didapat dengan mencari volume integral benda putar sebagai berikut:

$$
\mathrm{V}=\pi \int_{0}^{21.6}\left(\mathrm{y}_{\mathrm{awal}}^{2}-\mathrm{y}_{\mathrm{akhir}}{ }^{2}\right) \mathrm{dx}=1161.39 \mathrm{~m}^{3}
$$

Dikurangi luas daerah diluar $D$-wall sebesar $25 \%$, volume tanah didapat $=871.043 \mathrm{~m}^{3}$

Diketahui volume air yang dikeluarkan $77 \mathrm{~m}^{3}$, sehingga dapat dihitung storage coefficient:

$$
\mathrm{C}_{\mathrm{s}}=77 \mathrm{~m}^{3} / 871.043 \mathrm{~m}^{3}=0.088=8.8 \%
$$


Dengan hasil dari perhitungan volume tanah $\mathrm{C}_{\mathrm{s}}=8.8 \%$, diperbandingkan dengan nilai $\mathrm{C}_{\mathrm{s}}$ dari Soil Report dan dari referensi Specific Yield Analysis (Johnson: 1967) dalam tabel rangkuman sebagai berikut:

Tabel 7. Rangkuman perbandingan nilai $\mathrm{C}_{\mathrm{s}}$

\begin{tabular}{cc}
\hline Sumber & $\mathbf{C}_{\mathbf{s}}$ \\
\hline Analisis rumus & $8.8 \%$ \\
\hline Soil Report & $7 \%$ \\
\hline Referensi & $7-8 \%$ \\
\hline
\end{tabular}

Nilai $\mathrm{C}_{\mathrm{s}}$ dari volume tanah dengan rumus Darcy/Vesilind lebih tinggi hampir $2 \%$ dari nilai $\mathrm{C}_{\mathrm{s}}$ pada Soil Report. Dari referensi, $\mathrm{C}_{\mathrm{s}}$ untuk tanah jenis silty clay berkisar 7-8\%.

Pada luasan dan penurunan MAT yang sama, efek perbedaan $\mathrm{C}_{\mathrm{s}}$ sebesar $1 \%$ terhadap volume air yang dikeluarkan:

$$
\mathrm{Q}=871.043 \mathrm{~m}^{3} \times 0.01=8.7104 \mathrm{~m}^{3}
$$

\section{PENGARUH PERUBAHAN MAT TERHADAP TEGANGAN LATERAL PADA $D$ - $W A L L$}

Analisis 3 pada penelitian ini berfokus pada efek penurunan MAT pada kedua sisi cut-off wall yang digunakan pada Proyek X di Jl. Sudirman, yaitu $D$-wall. Dilakukan perbandingan lendutan pada $D$-wall dari kondisi awal dan kondisi akhir. Digunakan Rankine earth pressures sebagai pembebanan pada $D$-wall yang dimasukkan ke program GRASP untuk mencari lendutan pada tengah bentang terpanjang $D$-wall.

Data posisi MAT dimana terjadi perubahan paling drastis ditemukan pada Mei 2017 sebagai berikut:

Tabel 8. Data MAT pada 12 dan 17 Mei 2017

\begin{tabular}{ccc}
\hline Tanggal & $\begin{array}{c}\text { OW2 } \\
(\mathrm{m})\end{array}$ & $\begin{array}{c}\text { OW3 } \\
(\mathrm{m})\end{array}$ \\
\hline $12 \mathrm{Mei}$ & -25.15 & -12.65 \\
\hline $17 \mathrm{Mei}$ & -24.65 & -15.15 \\
\hline Perubahan & +0.50 & -2.50 \\
\hline
\end{tabular}

Posisi lantai basement yang digunakan sebagai perletakan sendi pada model $D$-wall dapat dilihat sebagai berikut:

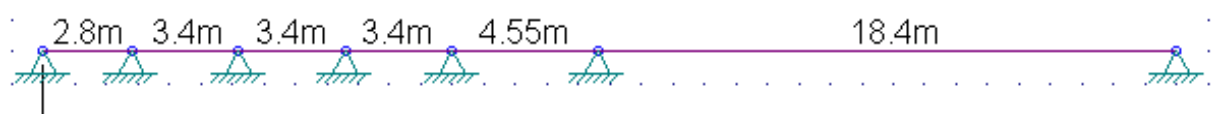

Gambar 10. Model D-wall dalam GRASP

Total panjang D-wall $36 \mathrm{~m}$ (mencapai kedalaman lapisan tanah keras) dengan asumsi lebar potongan $1 \mathrm{~m}$. Digunakan asumsi tanah keras sebagai perletakan sendi sesuai dengan teori fixed earth support (Bowles: 1997).

Data kekakuan $D$-wall: $\mathbf{E A}=\mathbf{1 . 8 7 6 2} \times 10^{7} \mathrm{kN} / \mathrm{m}$ dan $\mathbf{E I}=3.1437 \times 10^{6} \mathrm{kNm}^{2} / \mathrm{m}$

Digunakan 5 lapisan tanah untuk perhitungan pembebanan Rankine seperti berikut:

Tabel 9. Data 5 lapisan tanah untuk pembebanan Rankine

\begin{tabular}{cccccccc}
\hline Lapisan & $\begin{array}{c}\mathbf{H} \\
(\mathrm{m})\end{array}$ & $\begin{array}{c}\Delta \mathbf{H} \\
(\mathrm{m})\end{array}$ & Tipe & $\begin{array}{c}\boldsymbol{\gamma} \\
\left(\mathrm{kN} / \mathrm{m}^{3}\right)\end{array}$ & $\mathbf{P I}$ & $\begin{array}{c}\phi_{\mathbf{r}} \\
\left({ }^{\mathrm{o}}\right)\end{array}$ & $\mathbf{K a}$ \\
\hline 1 & 10.2 & 10.2 & silty clay & 18.17 & 42 & 16.1336 & 0.565094 \\
\hline 2 & 7.4 & 17.6 & clayey silt & 14.07 & 62 & 12.5411 & 0.643196 \\
\hline 3 & 4.9 & 22.5 & silty clay & 14.80 & 66.8 & 11.9277 & 0.657443 \\
\hline 4 & 5 & 27.5 & clayey silt & 15.04 & 46 & 17.3253 & 0.541073 \\
\hline 5 & 8.5 & 36 & silty clay & 17.49 & 29.2 & 19.4584 & 0.500238 \\
\hline
\end{tabular}


Digunakan data dari DB1 dan DB2, dengan rumus empiris untuk $\phi=$ sudut geser (Carter: 2016), dan $\mathrm{K}_{\mathrm{p}}$ (tekanan lateral pasif akibat kohesi) tidak diperhitungkan karena pada lapisan dengan nilai kohesi yang signifikan, posisi $D$ wall memiliki tanah pada kedua sisinya sehingga terjadi Kp yang simetris dan saling menghilangkan.

Contoh perhitungan untuk sudut geser dan $\mathrm{Ka}=$ tekanan lateral aktif (Terzaghi: 1996):

$$
\begin{gathered}
\phi_{r}^{\prime}=\phi=0.084 P I^{1.4}-0.75 P I+31.9=0.084 \times 42^{1.4}-0.75 \times 42+31.9=16.1336^{\circ} \\
K_{a}=\operatorname{Tan}^{2}\left(45^{\circ}-\frac{\phi}{2}\right)=\operatorname{Tan}^{2}\left(45^{\circ}-\frac{16.1336^{\circ}}{2}\right)=0.565094
\end{gathered}
$$

Beban lateral akibat tekanan air dapat dilihat pada tabel sebagai berikut:

Tabel 10. Pembebanan lateral tekanan air $\left(\mathrm{P}_{\mathrm{w}}\right)$

\begin{tabular}{ccccc}
\hline Tanggal & Posisi & $\begin{array}{c}\text { MAT } \\
(\mathrm{m})\end{array}$ & $\begin{array}{c}\mathbf{H}_{\mathbf{i}} \\
(\mathrm{m})\end{array}$ & $\begin{array}{c}\mathbf{P}_{\mathbf{w}} \\
(\mathrm{kN} / \mathrm{m})\end{array}$ \\
\hline \multirow{2}{*}{$12 \mathrm{Mei}$} & OW2 & -25.15 & 10.85 & 108.5 \\
\cline { 2 - 5 } & OW3 & -12.65 & 23.35 & 233.5 \\
\hline \multirow{2}{*}{$17 \mathrm{Mei}$} & OW2 & -24.65 & 11.35 & 113.5 \\
\cline { 2 - 5 } & OW3 & -15.15 & 20.85 & 208.5 \\
\hline
\end{tabular}

Contoh perhitungan pembebanan Rankine untuk tanggal 17 Mei 2017 dapat dilihat pada Tabel 11:

\begin{tabular}{|c|c|c|c|c|c|c|}
\hline 17 MEI & $\begin{array}{c}\text { Depth } \\
(\mathrm{m})\end{array}$ & OW2 & $\begin{array}{c}\mathbf{P a} \\
(\mathrm{kN} / \mathrm{m}) \\
\end{array}$ & $\begin{array}{c}\text { Depth } \\
(\mathrm{m})\end{array}$ & OW3 & $\begin{array}{c}\mathbf{P a} \\
(\mathrm{kN} / \mathrm{m}) \\
\end{array}$ \\
\hline Layer 1 & $0-10.2$ & - & - & $0-10.2$ & $1-1$ & 104.7312 \\
\hline \multirow[t]{5}{*}{ Layer 2} & \multirow[t]{5}{*}{$10.2-17.6$} & \multirow[t]{5}{*}{-} & \multirow[t]{5}{*}{-} & \multirow[t]{2}{*}{$10.2-15.15$} & $1-2$ & 119.2061 \\
\hline & & & & & 2-2 dry & 44.7964 \\
\hline & & & & \multirow[t]{3}{*}{$15.15-17.6$} & $1-2$ & 119.2061 \\
\hline & & & & & 2-2 dry & 44.7964 \\
\hline & & & & & 2-2 wet & 6.4136 \\
\hline \multirow[t]{3}{*}{ Layer 3} & \multirow[t]{3}{*}{$17.6-22.5$} & \multirow[t]{3}{*}{$3-3$} & \multirow[t]{3}{*}{47.6778} & \multirow[t]{3}{*}{$17.6-22.5$} & $1-3$ & 121.8466 \\
\hline & & & & & $2-3$ & 52.3443 \\
\hline & & & & & $3-3$ & 15.4631 \\
\hline \multirow[t]{5}{*}{ Layer 4} & \multirow[t]{2}{*}{$22.5-24.65$} & $3-4$ & 39.2386 & \multirow[t]{5}{*}{$22.5-27.5$} & $1-4$ & 100.2792 \\
\hline & & 4-4 dry & 17.4961 & & $2-4$ & 43.0792 \\
\hline & \multirow[t]{3}{*}{$24.65-27.5$} & $3-4$ & 39.2386 & & $3-4$ & 12.7260 \\
\hline & & 4-4 dry & 17.4961 & & $4-4$ & 13.6350 \\
\hline & & 4-4 wet & 7.7720 & & & \\
\hline \multirow[t]{5}{*}{ Layer 5} & \multirow[t]{5}{*}{$27.5-36$} & $3-5$ & 36.2773 & \multirow[t]{5}{*}{$27.5-36$} & $1-5$ & 92.7112 \\
\hline & & $4-5$ & 23.3611 & & $2-5$ & 39.8280 \\
\hline & & $5-5$ & 31.8477 & & $3-5$ & 11.7656 \\
\hline & & & & & $4-5$ & 12.6060 \\
\hline & & & & & $5-5$ & 31.8477 \\
\hline
\end{tabular}

Tabel 11. Pembebanan lateral Rankine 17 Mei 2017

Beban merata yang berbentuk segitiga ditegaskan dan dimiringkan, sisanya berupa beban merata biasa.

Contoh perhitungan untuk 17 Mei dapat dilihat sebagai berikut:

$$
\begin{aligned}
& P_{a 1-1}=0.565094 \times 18.17 \times 10.2=104.7312 \mathrm{kN} / \mathrm{m} \\
& P_{a 2-2 \text { wet }}=0.643196(14.07-10) 2.45=6.4139 \mathrm{kN} / \mathrm{m}
\end{aligned}
$$

Diagram pembebanan dan posisi MAT untuk kondisi awal dan kondisi akhir dapat dilihat sebagai berikut: 

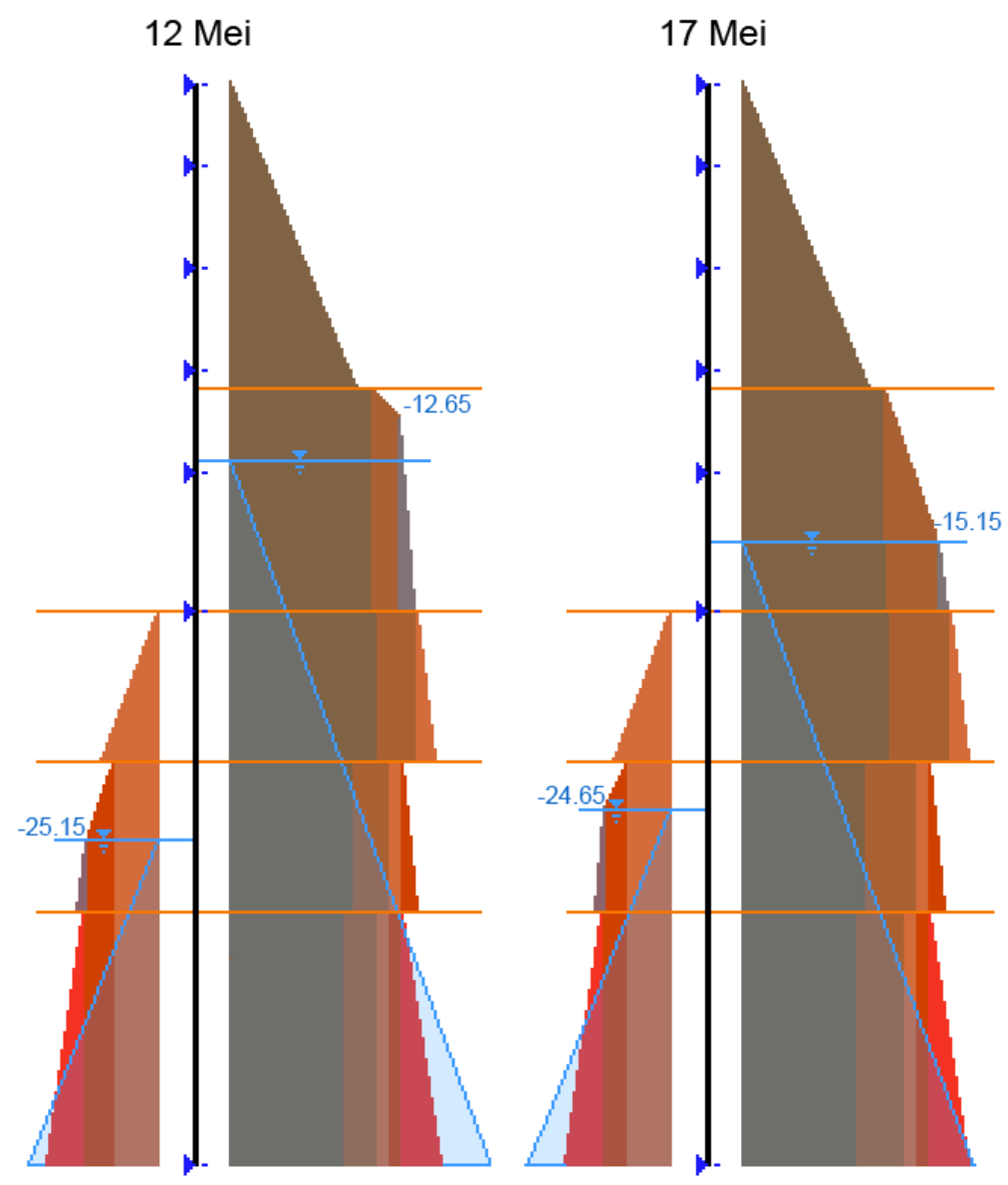

Gambar 11. Diagram pembebanan Rankine dan posisi MAT pada kedua sisi $D$-wall

Hasil perhitungan lendutan dalam program GRASP dapat dilihat sebagai berikut:

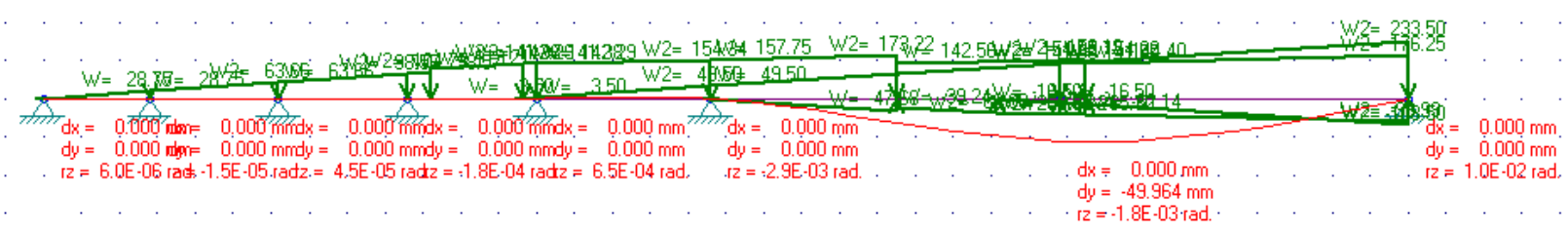

Gambar 12. Hasil perhitungan GRASP 12 Mei 2017 (49.964 mm)

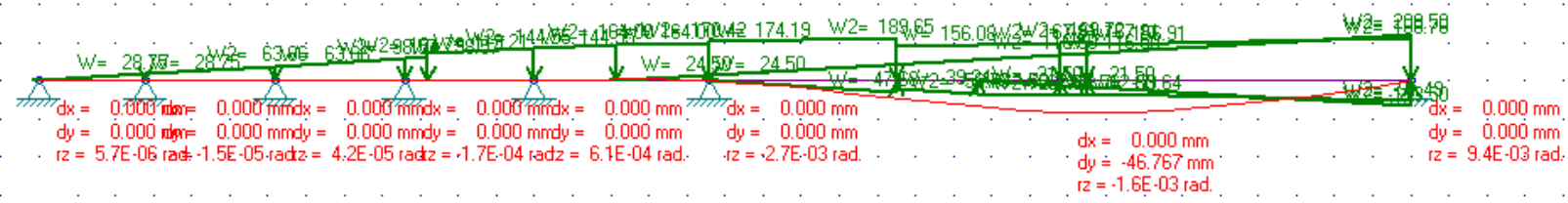

Gambar 13. Hasil perhitungan GRASP 17 Mei 2017 (46.767 mm)

Rangkuman perbedaan lendutan di tengah bentang terpanjang $D$-wall akibat perubahan MAT di kedua sisi $D$-wall dapat dilihat pada tabel sebagai berikut:

Tabel 13. Lendutan di tengah bentang terpanjang $D$-wall akibat perubahan MAT

\begin{tabular}{ccc}
\hline Tanggal & $\begin{array}{c}\text { Lendutan } \\
(\mathrm{mm})\end{array}$ & $\begin{array}{c}\Delta \text { MAT } \\
(\mathrm{m})\end{array}$ \\
\hline $12 \mathrm{Mei}$ & -49.964 & 12.5 \\
\hline $17 \mathrm{Mei}$ & -47.767 & 9.5 \\
\hline
\end{tabular}


Perubahan beda tinggi MAT sebanyak $3 \mathrm{~m}$ di kedua sisi $D$-wall (dari $12.5 \mathrm{~m}$ pada 12 Mei menjadi $9.5 \mathrm{~m}$ pada 17 Mei) mengakibatkan berkurangnya lendutan pada tengah bentang terpanjang $D$-wall sebesar $2.2 \mathrm{~mm}$. Hal tersebut disebabkan oleh berkurangnya beban lateral air yang bekerja pada $D$-wall.

\section{KESIMPULAN}

Dari ketiga analisis yang dilakukan, dapat ditarik kesimpulan berikut:

\section{Analisis 1: Koefisien permeabilitas (K)}

- Rumus K yang paling akurat adalah rumus Gustafson karena hasil MAT pada model SEEP/W persis sesuai dengan kondisi asli lapangan $(-25.1 \mathrm{~m})$.

- Nilai K dari rumus Darcy/Vesilind menghasilkan kondisi MAT pada model SEEP/W yang jauh dari kondisi asli lapangan $(-28.2 \mathrm{~m})$.

\section{Analisis 2: Storage coefficient $\left(\mathrm{C}_{\mathrm{s}}\right)$}

- Nilai $\mathrm{C}_{\mathrm{s}}$ pada tanah silty clay hasil analisis volume tanah dengan rumus Darcy/Vesilind (8.8\%) sedikit lebih tinggi dari nilai $\mathrm{C}_{\mathrm{s}}$ pada Soil Report (8\%) dan dari referensi (7-8\%).

- Untuk luasan tanah dan penurunan MAT yang sama, perbedaan $\mathrm{C}_{\mathrm{s}}$ sebesar 1\% pada volume tanah $871.043 \mathrm{~m} 3$ mempengaruhi volume air yang harus dikeluarkan sebesar $8.7104 \mathrm{~m}^{3}$.

\section{Analisis 3: Tegangan lateral Rankine}

- Perubahan beda tinggi MAT $(3 \mathrm{~m})$ pada kedua sisi $D$-wall mengakibatkan berkurangnya tekanan lateral air sehingga lendutan pada tengah bentang terpanjang $D$-wall berkurang sebesar $2.2 \mathrm{~mm}$.

\section{DAFTAR PUSTAKA}

Bilskie J. (2001). "Soil Water Status: Content and Potential”. Campbell Scientific, Inc.

Bowles, J.E. (1997). Foundation Analysis and Design. 5th ed. Singapore: McGraw-Hill.

Carter, M., Bentley, S.P. (2016). Soil Properties and their Correlations. 2nd ed. New York: John Wiley \& Sons.

Demirbas, K., A.B. Altan-Sakarya, and H. Onder. (2012). "Optimal Dewatering of an Excavation Site". Water Management Volume 165 Issue WM6 (Juni 2012). ICE Publishing.

GEO-SLOPE International Ltd. (2012). Seepage Modeling with SEEP/W. July 2012 ed., Calgary, Alberta.

Johnson, A.I. (1967). Specific Yield - Compilation of Specific Yields for Various Materials. Washington: United States Government Printing Office.

Powers, J.P. (1981). Construction Dewatering: A Guide to Theory and Practice. New York: John Wiley \& Sons.

Quinion, D.W. and Quinion, G.R. ICE Works Cosntruction Guides: Control of Groundwater. London: ICE Publishing, 1987.

Svensson, A. (2014). "Estimation of Hydraulic Conductivity from Grain Size Analyses". Disertasi, Chalmers University of Technology, Sweden.

Terzaghi, K., R.B. Peck, and G. Mesri. (1996). Soil mechanics in engineering practice, 3rd ed. New York: Wiley.

Vesilind, P.A., R.F. Weiner, and J.J. Peirce. (1994). Environmental Engineering. 3rd ed. Oxford: ButterworthHeinemann 